\title{
Formação de rede: uma alternativa de desenvolvimento profissional de alfabetizadores/as
}

Magda Soares

\author{
Professora aposentada \\ da Faculdade de Educação da \\ Universidade Federal de Minas \\ Gerais (UFMG) e assessora da \\ rede municipal de ensino de \\ Lagoa Santa \\ mbecker.soares@terra.com.br
}

\begin{abstract}
Resumo: Neste texto, transcrição de uma palestra realizada nos Encontros Abertos promovidos pela Cenpec ${ }^{1}$ em 18 se setembro de 2013, Magda Soares discute a formação de alfabetizadores com base em sua experiência no município mineiro de Lagoa Santa, onde tem realizado, desde 2007, um trabalho de desenvolvimento profissional de professores e de busca da melhoria da qualidade da educação no município. Sua experiência indica princípios ou diretrizes mais gerais para outros programas de formação docente.

Palavras-chave: Alfabetização. Formação de professores. Currículo.
\end{abstract}

\footnotetext{
N.E. A conferência constituiu também uma das atividades formativas da Plataforma do Letramento, projeto desenvolvido pelo Cenpec em parceria com a Fundação Volkswagen. O vídeo da conferência e o material utilizado por Magda Soares está acessível on line na Plataforma: 〈www.plataformadoletramento.org.br〉. 0 mesmo material está disponível no site do Cenpec em 〈http://www.cenpec.org.br/noticias/ler/Magda-Soaresespecialistas-do-Pa\%C3\%ADs-em-alfabetização,-ela-falou-sobre-o-projeto-que-vem-desenvolvendo-emLagoa-Santa-\%28MG\%29>.
} 
A proposta que me foi feita de expor o trabalho que venho desenvolvendo no município de Lagoa Santa me deixou um pouco tensa no início, mas ao mesmo tempo muito feliz em poder confrontar minha experiência com pessoas que têm as mesmas preocupações. Antes, contudo, gostaria de retomar minha trajetória de professora universitária e pesquisadora, para explicar o que me levou a este trabalho voluntário junto a uma rede pública, há já mais de oito anos.

Na Universidade, sozinha ou em parcerias com colegas (como o Antônio Batista²), trabalhei sempre com formação de professores. Após me aposentar na Universidade Federal de Minas Gerais (UFMG), decidi realizar um sonho que acalentava há muito tempo e esclarecer preocupações e dúvidas que eu tinha na Universidade. Trabalhando com formação de professores, tanto na formação chamada inicial nos cursos de Pedagogia e Licenciatura em Letras, quanto na formação chamada continuada em projetos que desenvolvíamos no Centro de Alfabetização, Leitura e Escrita da Faculdade de Educação da UFMG (Ceale) ${ }^{3}$, preocupações e insatisfações geravam em mim questões de duas naturezas.

A primeira questão era a dúvida sobre se a formação nos cursos universitários funcionaria na prática real. Nas pesquisas que eu fazia e orientava, o movimento de irmos à escola, verificar, descrever, analisar o que lá acontecia e voltar à universidade me mostrava que havia uma distância grande entre a formação dos professores e o que ocorre realmente nas escolas. Isso provocava em mim questionamentos como: o que as pesquisas descrevem e analisam (e quase sempre criticam) é o mesmo que realmente acontece no cotidiano escolar? Se é, por que acontece dessa maneira? Poderia ser diferente?

A segunda questão que meus estudos e pesquisas na Universidade me propunham - esta talvez mais séria e mais desafiadora - refere-se à qualidade da escola pública. Por que a escola pública não poderia ter a mesma qualidade da escola privada? Por que as crianças das camadas populares recebiam uma educação de menor qualidade? Por que passamos décadas e décadas

2 N.E. Antônio Batista é coordenador de Desenvolvimento de Pesquisas do Cenpec, foi orientando de Magda Soares e com ela colaborou estreitamente como professor da Faculdade de Educação da UFMG e membro do Centro de Alfabetização, Leitura e Escrita (Ceale).

3 N.E. O Ceale é um órgão complementar da Faculdade de Educação, criado, em 1990, por Magda Soares e por um grupo de professores da Faculdade de Educação e de Letras da UFMG, com o objetivo de promover uma forte articulação entre pesquisa, ensino e ação educacional em parceria com as redes públicas de ensino, no campo da alfabetização e do letramento. Ver: 〈http://www.ceale.fae.ufmg.br〉. 
lutando pela qualidade da educação pública e nunca conseguimos atingir essa qualidade? É possível ter qualidade na educação pública? Como? Quais os caminhos?

Essas questões me incomodavam muito, porque eu via que as mesmas condições que analisei no livro Linguagem e escola: uma perspectiva social ${ }^{4}$, nos já distantes anos 1980, ainda prevalecem, e as questões nele levantadas ainda são pertinentes. Na obra, eu defendia que as crianças das camadas populares não são deficientes, são diferentes, que diferença não é deficiência, e que seria possível uma educação de qualidade para essas crianças. 0 que para mim comprova que infelizmente as discussões propostas nesse livro ainda prevalecem, ainda são pertinentes, é que ele continua sendo editado, já está na 18a edição: o aspecto negativo dessas sucessivas reedições é que elas demonstram que os problemas levantados no livro permanecem.

Foram essas preocupações que me fizeram retornar, depois da aposentadoria, à escola pública, onde eu tinha começado minha carreira há 30 ou 40 anos, antes de ingressar na Universidade. Em um primeiro momento, voltei à escola em uma creche comunitária de um aglomerado de Belo Horizonte e, depois, em uma rede pública; sobre a experiência na rede pública é que vou me deter neste relato. Nas duas situações, realizei e realizo trabalho voluntário, porque queria ser colaboradora, não formadora de novo, só assim poderia viver a escola "de dentro"; isso também me ajudaria a vencer o "vício" do olhar de pesquisadora, que dificultaria esse viver a escola "de dentro".

Quis contextualizar brevemente minha trajetória para explicar como cheguei à experiência em uma rede pública, experiência que tem me dado grande satisfação, porque tenho aprendido muito mais do que aprendi na Universidade... E porque tenho visto resultados que me dão esperança.

FORMAÇÃO INICIAL, FORMAÇÃO CONTINUADA E DESENVOLVIMENTO PROFISSIONAL DE PROFESSORES

O propósito desta exposição é mostrar uma alternativa, não uma solução, de desenvolvimento profissional de alfabetizadores e de avanço na qualidade do ensino para crianças de escolas públicas.

$4 \quad$ N.E. Publicado pela editora Ática em 1986. 
Para situar essa alternativa, retomo os processos já bastante conhecidos de formação de professores: as tradicionalmente chamadas formação inicial e formação continuada. No que se refere aos níveis em que venho atuando na rede pública, educação infantil e séries iniciais do ensino fundamental, as modalidades de formação inicial dos professores são: Magistério, Normal Superior, Pedagogia.

O para mim saudoso Magistério (nele atuei nos meus anos de professora do ensino básico), ainda existente em alguns poucos contextos, é um curso cujo objetivo específico era a formação de professores para a educação infantil e as séries iniciais. O Normal Superior, curso em que depositei esperanças quando foi criado, esperanças que se frustraram, seria o Magistério elevado ao nível superior, com objetivos semelhantes, mas mais avançados. Infelizmente, foi uma proposta que não teve sucesso no País. Não sei se é de consenso geral, mas me parece que os cursos do chamado Normal Superior têm qualidade inferior ao que tinha o Magistério do passado. Já o curso de Pedagogia tem sido foco de uma luta de longa duração, para que realmente forme professores para a educação infantil e para os anos iniciais do ensino fundamental, o que não tem acontecido. Há uma resistência muito grande a qualquer mudança no currículo do curso de Pedagogia, que pode estar formando muito bem, pelo menos em várias instituições, especialistas em educação, mas não professores de sala de aula preparados para trabalhar nas séries iniciais e na educação infantil. Pode-se dizer que a situação atual é de ausência no País de uma formação inicial realmente destinada a professores que atuarão nessas etapas de escolarização.

Sobre a formação continuada, ainda para situar a alternativa que vem sendo desenvolvida no município de Lagoa Santa, proponho a distinção entre a formação continuada em rede e a formação continuada de rede. A mudança de preposição tem um propósito que vou explicitar.

A primeira expressão - formação continuada em rede - refere-se a uma articulação entre o Ministério da Educação (MEC), as universidades e os municípios que, organizando-se em uma rede, oferecem cursos aos professores em exercício. É uma rede que na verdade institui certa hierarquia, tendo o MEC no topo, em seguida as universidades, a quem o MEC propõe que assumam os cursos segundo normas estabelecidas em editais, e, por fim, os municípios, aos quais são oferecidos os cursos.

Essa formação em rede funciona por adesão, sistema sem dúvida de inspiração democrática, mas que pode, ao contrário, gerar resultados pouco 
democráticos. Assim: o MEC propõe às universidades adesão aos programas; os municípios, por sua vez, optam por aderir, ou não, aos cursos oferecidos pelas universidades para a formação continuada de seus professores; em cada município, os professores optam por seguir, ou não, os cursos. Como consequência, apesar de democrático, o processo pode ser excludente, porque resulta em "quem quiser crescer em formação cresce, quem não quiser, não cresce”, o que não parece justo quando se trata de educação de crianças e jovens, em que o que se pretende é que todos tenham direito a uma educação de qualidade. A educação não pode ficar sujeita à vontade dos que optaram por nela atuar de aderir ou não aderir à possibilidades de crescimento profissional.

Um segundo aspecto complicador nessa formação em rede, consequência em parte do formato por adesão, é que, geralmente, os cursos são em geral curtos, seguem uma programação prévia feita pelo MEC ou pelas universidades, ou por ambos em articulação, e professores que aderiram à proposta, de diferentes municípios e diferentes escolas, são reunidos para realizar o curso. Nesse quadro, ainda que haja grande esforço dos formadores para articular a proposta do curso com a prática pedagógica, essa articulação fica comprometida quando os envolvidos são profissionais com práticas diferenciadas, em territórios diferentes, em contextos diferentes, que assim não constituem um grupo com objetivos e necessidades comuns. Em decorrência, o que de mais proveitoso pode acontecer é um avanço individual de cada professor e uma melhor qualidade de suas turmas, em suas salas de aula. Não há uma melhora da escola como um todo, da rede como um todo, a não ser que haja um esforço grande do professor que fez o curso para dividir com os colegas as experiências e conhecimentos que o curso the tenha trazido, o que depende ainda de condições que a escola possa oferecer para que isso aconteça.

A alternativa a essa formação em rede, que temos desenvolvido no município de Lagoa Santa, é uma formação chamada “de rede”. Na formação de rede não há organização hierárquica. Pretende-se que a rede se constitua como uma coletividade, um conjunto de pessoas com os mesmos compromissos, tentando alcançar os mesmos objetivos, se esforçando na mesma direção. A formação de rede atinge a rede de ensino inteira: todos os professores, todos os gestores, todos os profissionais que atuam em todas as escolas, com o objetivo de promover o avanço na qualidade do ensino em todas as escolas igualmente, e no mesmo ritmo. Persegue-se uma homogeneidade na qualidade que não possibilite comparações entre escolas - a escola X é 
a melhor, a escola $Y$ é muito fraca -, que é o que tem acontecido quando são divulgados resultados de avaliações externas nacionais ou estaduais: os jornais noticiam que em determinado município há uma escola que atingiu um Índice de Desenvolvimento da Educação Básica (IDEB) altíssimo, que uma escola no município $X$ teve resultados muito acima da média na Prova Brasil... 0 alto Ideb e os resultados muito acima da média são, sem dúvida, uma realização louvável para aquelas escolas especificamente, mas as informações só reforçam que a educação não está bem no País, porque são tão poucas as escolas que se destacam que é preciso dar-lhes o reconhecimento que merecem. Não é isso que desejamos para a educação brasileira: temos de perseguir um crescimento da qualidade em todas as escolas, para todas as crianças. Em um País de dimensões continentais, não é uma tarefa simples, mas a alternativa da formação de rede em Lagoa Santa é o que eu chamaria de uma microprática que pode contribuir para pensarmos uma formação que atinja todas as escolas de um município. Talvez o caminho para este País de dimensões continentais seja tomar como unidades os municípios.

A experiência em Lagoa Santa foi inicialmente definida como uma formação de rede por meio da formação continuada dos professores ${ }^{5}$. Ao conhecer 0 projeto, um colega da Faculdade de Educação da UFMG, o professor Júlio Emílio Diniz Pereira, caracterizou o que fazemos como desenvolvimento profissional dos professores, não como formação continuada. E realmente é o que acontece: os professores já estão no exercício da profissão, já se formaram em cursos de graduação de Pedagogia ou Normal Superior, o que se busca não é continuar essa formação, mas sim o desenvolvimento profissional no contexto da prática docente: das experiências, problemas, dificuldades, dúvidas que ela suscita a cada momento. Aliás, em todas as profissões, é após a formação, no exercício profissional, que as pessoas desenvolvem competências que só a prática possibilita.

\section{ARTICULAÇÃO TEORIA-PRÁTICA}

O que de mais importante aprendi e tenho aprendido neste projeto em Lagoa Santa é o verdadeiro significado da articulação teoria-prática, de que tanto

5 N.E. Lagoa Santa é um município da Região Metropolitana de Belo Horizonte afetado pelo crescimento do Vetor Norte da Capital mineira: sua população praticamente dobrou entre 1991 e 2010. Mais à frente são fornecidas informações sobre sua rede de ensino. 
falamos na Universidade. Fiquei nela quase 40 anos realizando pesquisas, estudando, formando professores, lendo e escrevendo livros e considerando que, com base em tudo isso, sabia o que deveria ser feito nas escolas. Quando cheguei à rede e às escolas, e defrontei com a realidade cotidiana da vida escolar, percebi quanto nossas teorias ora não funcionam, ora funcionam mal, ora podem clarear problemas e assim melhorar a prática, ora precisam ser reformuladas com base na prática... Concluí que não sabemos o que realmente significa a relação teoria-prática quando estamos na Universidade, inseridos em uma instituição essencialmente acadêmica, que exige presença por 40 horas semanais, com dedicação exclusiva, de modo que a única oportunidade de ir à escola é para buscar dados para pesquisas. Quando mergulhamos na vida escolar, numa inserção de parceria e colaboração, percebemos que a relação entre teoria e prática não é tão simples como parecia, como se pensava, que é complexa e, sobretudo, que é de grande riqueza e potencialidade.

A experiência de estar há oito anos vivenciando a inserção em uma rede pública me levou a identificar alguns aspectos em que a relação teoria-prática tal como a consideramos na Universidade não se confirma na realidade das redes e das escolas.

Um primeiro aspecto é o confronto da gestão na educação com a realidade das redes públicas. Muda de quatro em quatro anos a gestão do município e, consequentemente, mudam a gestão da secretaria de educação e as equipes pedagógicas centrais; assim, a cada nova gestão, cada uma com suas características, objetivos, pressupostos político-ideológicos, é preciso agir para manter projetos, implantados por gestão anterior, em andamento. Essas alterações alteram práticas e a relação delas com teorias.

Um segundo aspecto é que, em educação, as relações teoria-prática não são as mesmas em contextos diferentes, mesmo no interior de um município. No caso de Lagoa Santa, como ocorre na quase totalidade dos municípios brasileiros, as escolas se localizam em territórios muito diferentes, o que gera uma articulação também diferente entre teoria e prática em cada local. Na formação de professores na Universidade e no modelo de formação continuada em rede, cursos são oferecidos e considera-se que o grupo de professores que deles participam é homogêneo. Mas cada participante trabalha onde? Em que contexto? Com quais características?

Um terceiro aspecto que evidencia a distância entre nossas teorias e a prática nas escolas é articulação destas com as famílias. Teorias afirmam que as famílias devem participar da educação das crianças, frequentar a escola, 
colaborar com a educação dos filhos. O que se constata em geral nas escolas públicas, com algumas exceções, é que as famílias não têm condições reais, concretas, de realmente participar da educação das crianças no nível que a escola demanda, porque vivem situações muito difíceis, muitas vezes os pais não têm escolaridade suficiente para ajudar no dever de casa, para ler histórias para as crianças... É comum o não comparecimento dos pais a reuniões da escola, embora a grande maioria manifeste grande interesse na escolarização dos filhos. Na verdade, as teorias partem de uma visão idealizada da família que se choca com a prática.

Finalmente, um último aspecto da inadequação à realidade das escolas da relação teoria-prática tal como é concebida na Universidade está na pressuposição de que a formação continuada existe para preencher lacunas na formação inicial dos professores. Realmente há lacunas a preencher, já que os cursos, como disse, não formam professores, mas especialistas em educação; mas o que os cursos de formação continuada, ainda que pretendam preencher as lacunas, ignoram é que as professoras já chegam sabendo muito, que elas constroem permanentemente saberes sobre o ensino e a aprendizagem, sobre as possibilidades e os limites do contexto escolar, o que obriga a reconstruir o conceito de prática e sua relação com teorias. 0 que tenho vivenciado durante este tempo de inserção nas escolas me fez perceber que seria uma pretensão considerar que estou "formando" as professoras da rede municipal. Não estou formando as professoras; na verdade, elas estão me formando tanto quanto eu estou formando-as. Estamos nos desenvolvendo profissionalmente, tanto eu quanto elas, também eu estou me desenvolvendo profissionalmente.

\section{O PROJETO DE DESENVOLVIMENTO PROFISSIONAL DE ALFABETIZADORES}

Chego finalmente à descrição do projeto que vem sendo desenvolvido no município de Lagoa Santa. Caracterizei o projeto como uma microprática e explicito o sentido de micro: é uma alternativa micro no sentido geográfico, porque se realiza em um só município dos mais de 5.500 municípios brasileiros; e é micro no sentido curricular, porque focaliza apenas a área da aprendizagem inicial da língua escrita, que engloba alfabetização - a aquisição de uma tecnologia, o sistema alfabético e ortográfico da escrita - e letramento - o desenvolvimento de habilidades de uso da tecnologia da escrita. 0 projeto em Lagoa Santa se denomina Projeto Alfaletrar porque entende a aprendizagem da língua escrita como uma articulação entre alfabetizar e letrar. 
O Projeto Alfaletrar considera inicial a aprendizagem que se desenvolve durante a educação infantil e o primeiro segmento do ensino fundamental (cinco primeiros anos ou séries). Durante todo esse período, trabalhamos com alfabetização e com letramento. Em uma síntese do que se desenvolve durante esse período: no que se refere à alfabetização, o passo essencial é que a criança redescubra que a escrita alfabética, esta tecnologia inventada pela humanidade há 3 ou 4 mil anos, não representa o significado das palavras como o desenho, mas representa os sons das palavras por traços arbitrários, as letras. Dado esse passo essencial, a criança precisa descobrir que a cadeia sonora das palavras pode ser segmentada em sílabas e estas em fonemas, que são entidades abstratas, que não se consegue pronunciar isoladamente, e que são aquilo que as letras representam. Compreendido assim o princípio alfabético, a criança precisa aprender as normas ortográficas, ou seja, as convenções para uso do sistema alfabético. Tudo isso em contexto de letramento, a criança realizando esse trajeto por meio de convivência e experiências com material escrito, diferentes portadores de texto, diferentes gêneros, ao mesmo tempo ampliando sua compreensão dos usos sociais da escrita e seu interesse por eles. Assim, desde a educação infantil, a criança vai trilhando o caminho da alfabetização e do letramento: vai aprendendo a tecnologia da escrita e aprendendo a fazer uso dessa tecnologia.

É este o fundamento e o objetivo do Projeto Alfaletrar: aprender a tecnologia da escrita para ter condições de desenvolver habilidades de seu uso, desenvolver habilidades de uso para ampliar o domínio da tecnologia. A concretização desse objetivo se faz por meio do desenvolvimento profissional de todas as professoras da rede municipal de ensino, na área de alfabetização e letramento, incluindo desde as professoras que atuam na creche até as que atuam no $5^{\circ}$ ano.

O trabalho no município de Lagoa Santa foi iniciado em 2007. 0 nome da cidade vem de uma grande lagoa em torno da qual ela se desenvolveu, e que foi considerada, em tempos distantes, como sendo de águas que curavam, por isso santas; muitas pessoas conhecem a cidade como o lugar em que Peter Lund ${ }^{6}$ passou parte da vida nas cavernas e grutas da região; foi em uma delas que encontraram o fóssil humano mais antigo das Américas, um crânio de mulher que ganhou o nome de Luzia.

6 Naturalista dinamarquês que estudou fósseis em cavernas brasileiras. Em 1843 encontrou na região vestígios de homens pré-históricos, cujos estudos definiram as características daquele que ficaria conhecido posteriormente como o Homem de Lagoa Santa. 
A rede municipal de Lagoa Santa é atualmente composta por 21 escolas bastante diversas entre si quanto a segmentos que atendem, número de alunos, localização no extenso território do município, o que exige do Projeto um trabalho diferenciado. Três instituições atendem crianças de 0 a 5 anos. Duas escolas atendem somente parte da educação infantil, a pré-escola, ou seja, crianças de 4 e 5 anos. Sete escolas atendem, além da pré-escola, o

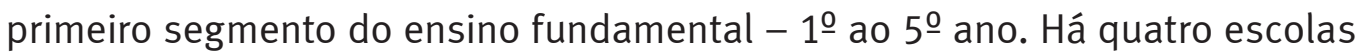
que oferecem parte da educação infantil e todo o ensino fundamental, até o 9 음 ano, e ainda três escolas que oferecem somente o primeiro segmento do ensino fundamental, e duas escolas que oferecem todos os anos do ensino fundamental. Há, assim, uma diversidade de perfis de escola e de contextos escolares, no que se refere aos níveis oferecidos em cada um, e temos percebido como isso exerce influência sobre o ensino e a aprendizagem. Não são muitas escolas, mas é um número que representa aproximadamente a média de escolas nos municípios brasileiros, excetuados, naturalmente, aqueles em que estão as capitais e também as cidades mais populosas.

\section{Começando pelas bibliotecas escolares}

As escolas do município de Lagoa Santa têm em geral uma boa infraestrutura, estão em prédios bons ou, pelo menos, razoáveis. No período de implantação do Projeto, em 2007, ao visitar as escolas, uma das principais preocupações era conhecer a biblioteca, certamente essencial para um projeto de alfabetização e letramento. Como acontece em grande parte do País, em algumas escolas havia uma sala que chamavam de biblioteca, mas era não mais que um depósito de livros didáticos: livros didáticos antigos, remanescentes dos que haviam sido enviados em anos anteriores pelo Programa Nacional do Livro Didático (PNLD), não mais usados. Em outras escolas, o local denominado como biblioteca era ao mesmo tempo sala de professores, sala de castigo, sala de reuniões, sala das mais diversas ocupações. Várias escolas não tinham local a que dessem o nome de biblioteca. Por isso, a primeira providência, na implantação do Projeto Alfaletrar, foi uma negociação com o prefeito e com a secretária de Educação para instalarmos verdadeiras bibliotecas em todas as escolas, transformando espaços já chamados "biblioteca” ou redirecionando espaços até então destinados a outros fins, e mesmo conseguindo da prefeitura a construção de espaços: a existência de biblioteca nas escolas era condição para a continuidade do projeto. No final do ano de 2007 , todas as escolas tinham bibliotecas, predominantemente de literatura infantil e juvenil, 
por isso denominadas "bibliotecas literárias"; o objetivo era, e é, colocar o foco no letramento literário das crianças.

Já no primeiro momento, conseguimos muitos livros para as bibliotecas: livros recebidos do Programa Nacional de Biblioteca da Escola (PNBE), caixas de livros literários e caixas dos chamados "materiais complementares". Além disso, estamos articulados com várias editoras que nos fazem doações; a Secretaria de Educação compra anualmente livros e as próprias escolas gastam parte de sua verba de "pequenos gastos" com a compra de livros para a biblioteca. As bibliotecas passaram a ser privilegiadas na rede, sobretudo porque as atividades do Projeto incentivam seu uso de forma intensa. Criamos nosso próprio processo de organização dos livros, adequado às crianças a que prioritariamente se destinam as bibliotecas. Usamos um processo de identificação dos livros por cores. Por exemplo, livros de poesia são identificados por uma fita adesiva azul na lombada, assim a criança, mesmo a que ainda está se alfabetizando, se quiser ler poemas, saberá onde encontrá-los, e saberá onde colocar o livro ao devolvê-lo à estante. Cada gênero, e os subgêneros, quando é o caso (por exemplo, no gênero prosa, os contos de fada, os contos clássicos, os contos de bruxa, etc.), é identificado por uma cor diferente. Esse processo também ajuda as crianças a construírem o conceito de gênero.

Outro aspecto importante na organização das bibliotecas foi decidir como posicionar os livros de modo a deixar expostas as capas, já que, em livro infantil, é sobretudo a capa que atrai primeiro a criança. Comprar estantes sofisticadas não era possível. As próprias professoras criaram, então, como alternativa, bolsões de plástico para colocar os livros, expondo a capa. Uma alternativa foi usartrilho de cortina em que se podem colocar os livros apoiados, em pé. Aprendi, e tenho aprendido, que não há nada que supere a criatividade das professoras para achar soluções brilhantes para os problemas. As nossas bibliotecas são lindas e acolhedoras: há tapetes, almofadas, e vejo sempre crianças deitadas nas almofadas lendo. São desenvolvidas atividades das professoras na biblioteca, com sua turma, e atividades promovidas pela professora encarregada da biblioteca (não há, no quadro de pessoal da rede, o cargo de bibliotecário/a, tem sido responsabilidade do Projeto Alfaletrar orientar as "professoras de biblioteca"). 


\section{Professoras formando professoras}

A estratégia para desenvolver o projeto em toda a rede, em todas as 21 escolas, chegando a todas as professoras, foi a criação de um Núcleo de Alfabetização e Letramento, constituído por uma professora de cada escola, escolhida pelas colegas como sua representante no Núcleo. Embora tivesse sido uma possibilidade inicialmente pensada, não se optou por constituir o Núcleo com as coordenadoras pedagógicas, porque em geral não têm prática de sala de aula e, sobretudo, sua posição nas escolas é hierarquicamente superior à das professoras, quando é importante que as professoras participantes do Núcleo sejam vistas como iguais, colega escolhida pelas colegas, tendo, assim, condições de exercer a necessária liderança nas atividades de alfabetização e letramento, cada uma em sua escola.

O Núcleo, que eu coordeno, se reúne toda semana na tarde de segundafeira e, eventualmente, na manhã de terça-feira. Nas reuniões, discutimos as questões que surgem na prática; ficou logo a princípio evidente que o que é considerado problema de aprendizagem dos alunos resulta, na verdade, de faltarem às professoras conhecimentos sobre os processos cognitivos e os fundamentos linguísticos de aprendizagem da língua escrita. Ao mesmo tempo que esses processos vão sendo esclarecidos, novos procedimentos de ensino são sugeridos e experimentados. Em geral, as professoras do Núcleo ou as professoras das escolas criam elas mesmas novas estratégias - já mencionei a surpreendente criatividade de quem está cotidianamente na prática para criar procedimentos e estratégias. Nas escolas reserva-se um horário mensal - não conseguimos mais que isso, nos apertados limites dos horários curriculares - em que cada professora do Núcleo se reúne com todas as professoras de sua escola, com a presença também da diretora e das coordenadoras pedagógicas, para apresentar e discutir o que foi tema das reuniões do Núcleo, as dificuldades que tenham surgido no processo de alfabetização e letramento, os procedimentos que uma ou outra professora tentou e deu certo, ou deu errado... O que ocorre nessas reuniões é relatado nos encontros semanais do Núcleo, é discutido e esclarecido, levado de volta para a escola. Nas escolas, as professoras do Núcleo atuam como permanente apoio às colegas, são procuradas para orientações e ajuda nas dificuldades, orientam as professoras das bibliotecas. Aos poucos se tornaram tão requisitadas que começaram a ficar muito sobrecarregadas, acumulando o ensino com a orientação das colegas e a supervisão da biblioteca. Atualmente, elas ficam exclusivamente responsáveis pela orientação das colegas e da biblioteca, pelo apoio a todas as atividades de alfabetização e letramento na escola. 
As atividades criadas pelas professoras nas escolas para desenvolver as propostas do Projeto são tão ricas que realizamos duas exposições em cada ano. No primeiro semestre, a exposição é a Paralfaletrar, em que as professoras expõem, umas para as outras, para a comunidade e também para professoras de municípios vizinhos, alunos de cursos de Pedagogia de faculdades da região, os procedimentos, materiais, jogos, etc. que criaram para alfabetizar em contexto de letramento - daí o nome Paralfaletrar. No segundo semestre, a exposição se chama Alfalendo, e nela são expostos os trabalhos produzidos pelas crianças a partir de livros de literatura infantil que leram e discutiram durante o ano.

Desenvolvendo-se dessa forma, o Projeto criou em todos os professores um espírito de rede: tudo é socializado, tudo é feito igualmente em todas as escolas, tudo é discutido coletivamente, tudo é trocado entre escolas, entre professores, todos se sentem responsáveis pela qualidade do ensino na rede, para além de por sua escola, por sua turma. O Projeto não é visto como vindo de cima ou de fora, é um projeto construído pela rede, um projeto da rede. Isso em grande parte é que tem garantido que as gestões municipais mudem e o Projeto continue. Um fato é exemplo dessa responsabilidade de todos pelo Projeto. Em 2012 os professores estavam planejando uma greve por carreira e salário, e combinavam em assembleia uma paralisação em determinado dia para manifestação diante da prefeitura. No momento de decidir o dia da paralisação, o presidente do sindicato propôs a segunda quarta-feira do mês que se iniciava. Uma professora, que nem mesmo era integrante do Núcleo, contestou: "Esse dia não pode ser, porque é o dia da reunião nas escolas com a professora do Núcleo". (As reuniões ocorrem sempre na segunda quartafeira de cada mês.) A decisão foi que a reunião tinha de ser preservada, e escolheram outro dia para a manifestação. Foi um incidente que mostrou como o Projeto é incorporado pelos professores como um projeto deles, da rede.

\section{Princípios do Projeto Alfaletrar}

Mas já é tempo de relatar o que é o Projeto Alfaletrar, quais são os princípios em que se fundamenta, como se desenvolve ao longo dos anos, da educação infantil ao $5^{\circ}$ ano do ensino fundamental.

Os princípios do Projeto garantem a formação de rede, e são basicamente quatro: continuidade, integração, sistematização e acompanhamento.

A continuidade se realiza de várias maneiras. O Projeto está construído para o desenvolvimento da alfabetização e do letramento ao longo da educação 
infantil e dos anos iniciais do ensino fundamental, é concebido como um continuum. Cada professora se vê como um elo de uma corrente que continua o que foi feito antes e prepara o que vai ser feito depois. Para isso, os conteúdos são estruturados de modo que haja um crescimento contínuo, ano a ano. E são distribuídos de forma que cada conteúdo se relacione com os demais conteúdos, garantindo a integração entre os componentes do processo de alfabetização e letramento. Por exemplo, as professoras que lecionam no $2 \stackrel{0}{ }$ ano trabalham em interação com as professoras do $1^{0}$ ano e do $3^{\circ}$ ano; as professoras que lecionam no $1^{0}$ ano interagem com as professoras de educação infantil e do $2^{0}$ ano. Ou seja, cada professora sabe o que foi feito antes, o que as crianças realizaram, como estão essas crianças, sabe de onde começar, o que tem de suprir que não foi alcançado no ano anterior; e sabe o que ela deve desenvolver para que as crianças estejam em condições de prosseguir sem dificuldades no ano seguinte. É assim que a integração se concretiza.

Conteúdos e habilidades são desenvolvidos com continuidade e integração, mas sempre com sistematização. Em minha experiência ao longo do tempo em que convivi com escolas públicas, sempre me surpreendeu a ausência de sistematização no ensino. Professoras realizam muitas atividades, mas de forma desarticulada, selecionando-as aleatoriamente, havendo mesmo em algumas escolas uma "caixa de atividades", com propostas entre as quais professoras escolhiam a que naquele dia reproduziria para uso com seus alunos, sem considerar como aquela atividade se inseria no processo de aprendizagem do aluno: o que veio antes? 0 que vem depois? Respeitando o princípio da sistematização, o ensino se organiza em uma sequência que acompanha o processo de aprendizagem do aluno, cada momento avançando em relação ao que foi realizado, preparando o que virá em seguida. Essa sistematização é fundamental e exige um acompanhamento permanente, o quarto princípio do Projeto, a fim de diagnosticar se continuidade, integração, sistematização estão garantindo qualidade de aprendizagem dos alunos.

Uma das formas de concretização da continuidade é a organização em ciclos. Embora seja uma organização já bastante difundida, o que acontece em muitos casos é que ela não altera realmente o funcionamento do ensino. Em Lagoa Santa, o Projeto tem conseguido que o ensino funcione realmente em ciclos, com continuidade e integração dentro de cada ciclo e entre um ciclo e outro: um Ciclo de Introdução à alfabetização e ao letramento, que vai da creche ao infantil II, seguido do Ciclo Básico, do $1^{0}$ ao $3^{\circ}$ ano do ensino fundamental, em que se completa a alfabetização e se avança no letramento, seguido do Ciclo de Consolidação, que engloba os $4^{\circ}$ e $5^{\circ}$ anos, em que se 
consolida a alfabetização e se aperfeiçoa a ortografia, sempre em contexto de letramento. A Figura 1 representa essa organização:

Figura 1 - Organograma da organização

em ciclos da educação infantil ao ensino fundamental.

\section{EDUCAÇ̃̃O INFANTIL ENSINO FUNDAMENTAL}

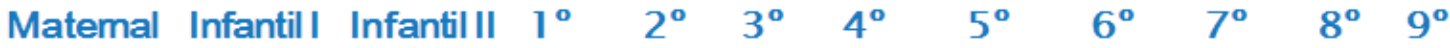

\begin{tabular}{|c|c|c|c|}
\hline CICLO DE INTRODUÇÃO & $\begin{array}{l}\text { CICLO } \\
\text { BÁSICO }\end{array}$ & & \\
\hline & & $\begin{array}{c}\text { CICLODE } \\
\text { CONSOL- } \\
\text { DAÇÃO }\end{array}$ & \\
\hline & & & $\begin{array}{l}\text { CICLO DE } \\
\text { AMPLIAÇÃO }\end{array}$ \\
\hline
\end{tabular}

Para reforçar a continuidade e a integração intraciclo e interciclos, as exposições mencionadas, Paralfaletrar e Alfalendo, são organizadas por ciclo: cada ciclo tem seu espaço na exposição. Dessa maneira, é possível às professoras de toda a rede ver o que cada ciclo realiza, a relação de cada um com o anterior e com o seguinte.

Para orientar essa integração e continuidade, os componentes do processo de alfabetização e letramento são distribuídos ao longo dos ciclos, como mostra a Figura 2, que todas as professoras têm e está em geral exposto na sala de professores: 
Figura 2 - Organograma da continuidade e integração em alfabetização e letramento do maternal ao $5^{\circ}$ ano do ensino fundamental.

Mat. Inf.IInf.II $1^{\circ} \quad 2^{\circ} \quad 3^{\circ} \quad 4^{\circ} \quad 5^{\circ}$

Consciência fonológica e alfabeto

Consciência fonêmica - ortografia

Linguagem oral

Tecnologia da escrita

Escrita de palavras

Produção de textos

Leitura de palavras

Leitura oral de textos

Leitura silenciosa de textos

Compreensão de textos

Vocabulário

Reflexão sobre a língua

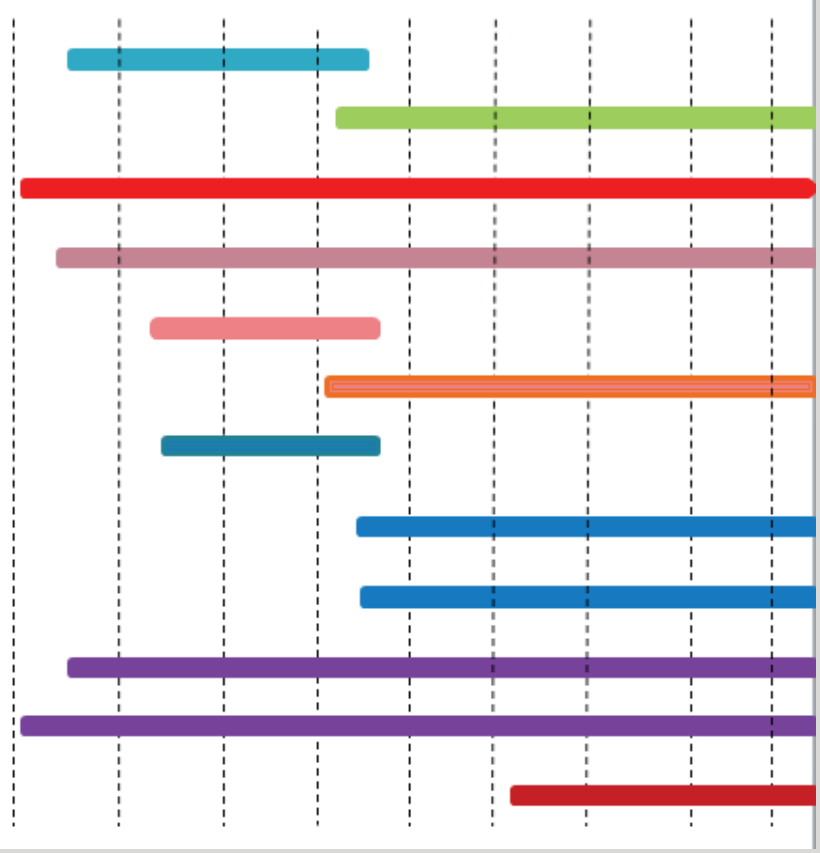

Analiso rapidamente as linhas da Figura 2. Atividades de consciência fonológica se iniciam no maternal, quando já se trabalham parlendas, poemas, cantigas, não só para que a criança desenvolva a oralidade, mas também para que volte sua atenção para a cadeia sonora da fala. São atividades que buscam levar a criança a focalizar os sons das palavras, base para a aprendizagem da escrita, pois esta depende da compreensão de que se grafam os sons das palavras, o significante, e não o significado. 0 trabalho com consciência fonológica continua, como mostra a Figura 2, no infantil I, no infantil II, no $1^{0}$ ano do ensino fundamental. No $1^{\mathfrak{0}}$ ano, deseja-se que a criança esteja em condições de desenvolver a consciência fonêmica, as correspondências fonema-grafema e grafema-fonema. 0 eixo para o desenvolvimento de consciência fonológica e conhecimento das letras são as fases de conceitualização da escrita na orientação psicogenética: o avanço de uma fase para outra depende do desenvolvimento da consciência fonológica, pois a criança se torna silábica quando compreende que a palavra sonora pode ser segmentada em sílabas, ou seja, quando adquire consciência silábica, torna-se alfabética quando identifica, na sílaba, os fonemas; simultaneamente, a criança vai aprendendo que é com letras que ela representa os sons, e então representa cada sílaba por uma letra, depois cada fonema por uma letra. Assim, paralelamente ao desenvolvimento da consciência fonológica, trabalha-se o alfabeto, 
relacionando as letras com os sons das palavras. Não é fácil o trabalho com as letras, porque a criança inicialmente considera as letras como objetos, o que a leva a pensar que não importa a posição delas, tal como qualquer objeto, em qualquer posição, é sempre o mesmo objeto; é o que pode levar à escrita espelhada, em que a criança não diferencia $p$ de $q$, ou $b$ de $d$. Trabalhar com o alfabeto significa levar a criança a compreender que as letras são representações arbitrárias em que uma rotação horizontal, como de $b$ e $d$, ou vertical, como de $p$ e $q$, transforma a letra em outra letra.

A Figura 3 representa esse desenvolvimento simultâneo da conceitualização da escrita, da consciência fonológica e do conhecimento das letras:

Figura 3 - Esquema: alfabetização - continuidade, integração, sistematização.

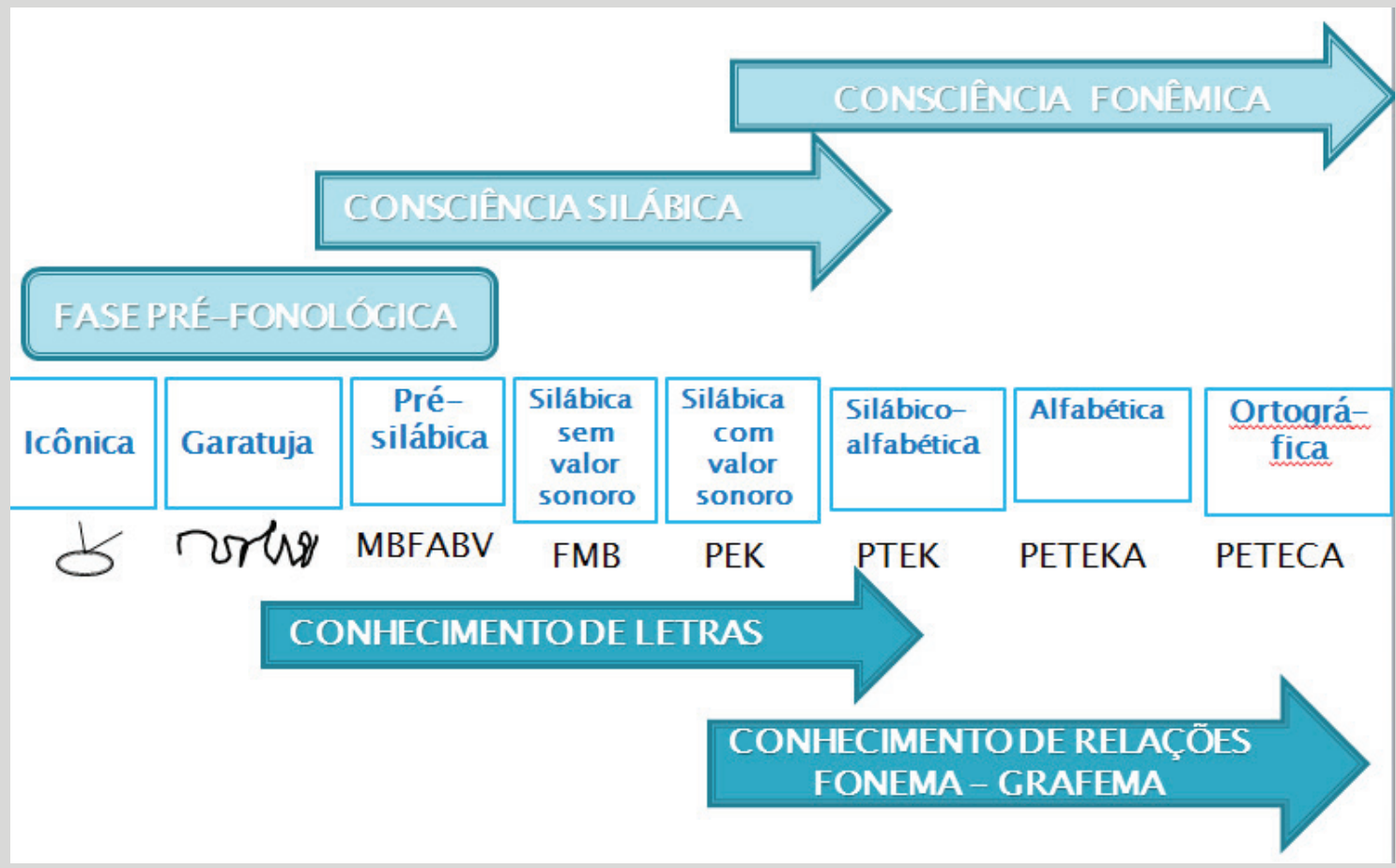

Dando continuidade à análise das linhas da Figura 2, atividades de tecnologia da escrita estão presentes desde o maternal, quando se dão lápis e papel para que a criança rabisque, já aprendendo a lidar com o suporte e o instrumento da escrita. No infantil I e no infantil II, as crianças já começam a escrever palavras, não só a "escrita inventada”, também chamada "criativa”, em que a criança escreve "do jeito que sabe", evidenciando suas hipóteses sobre a escrita, mas também aprende a escrever, porque sempre deseja isso, o nome da mãe, do pai, da professora, o nome dela mesma. 
A partir do $1^{0}$ ano, avançamos da escrita da palavra para a produção de textos, de início textos pequenos que ao longo das séries vão crescendo em tamanho e complexidade. Desde a educação infantil começamos a trabalhar com recontos, a professora atuando como escriba enquanto a criança não é ainda capaz de escrever ela mesma; o reconto é um gênero que permite à criança concentrar-se mais na forma que no conteúdo, já que este já é dado. Mas se trabalha também com outros gêneros de texto que são "para escrever" - discutimos muito quais gêneros são sobretudo para ler, quais gêneros é preciso aprender a escrever.

Também a leitura parte da palavra: escrevendo palavras, a criança está também lendo palavras. Progressivamente, como se vê no organograma, a criança avança para a leitura de textos: inicialmente pequenos, pouco complexos, aos poucos textos mais longos, mais complexos. Trabalha-se tanto a leitura oral quanto a leitura silenciosa. A leitura silenciosa precisa ser desenvolvida, pois a leitura oral gera um comportamento a que as professoras sempre se referem: a criança lê oralmente, mas, quando questionada sobre o que leu, não sabe responder porque, concentrada em decifrar, em oralizar, não compreendeu o que leu.

Desenvolver a compreensão de texto é importante desde o maternal, como está na Figura 2: a professora lê uma história para a criança e faz perguntas, antes, durante e depois da leitura, não quaisquer perguntas, mas perguntas previamente planejadas de forma a desenvolver diferentes estratégias de leitura - as professoras se orientam por um quadro de estratégias de leitura que foi discutido nos encontros do Núcleo. Atividades de vocabulário estão estreitamente ligadas à leitura e compreensão de textos. Fundamental na educação infantil para ampliação da linguagem oral da criança, continua fundamental nos anos seguintes, ampliando o universo linguístico, oral e escrito.

Para selecionar livros e textos adequados a cada ano, a cada idade, é preciso analisar o nível de complexidade do texto; a tendência é, geralmente, classificar textos por seu tamanho, mas este não é o principal critério. Nos encontros do Núcleo, discutimos um quadro que construí apresentando critérios para definir a adequação de textos a diferentes anos e idades. As professoras analisaram textos, aplicando os critérios. Por exemplo, analisamos uma mesma fábula em diferentes versões; em grupos, as professoras classificaram as versões da mais fácil à mais difícil, orientando-se pelos critérios, e se espantaram ao perceber que a versão mais complexa era o texto mais curto, o que possibilitou 
perceber que a escolha de livros e textos para diferentes anos e idades não deve ser feita somente com base no tamanho do texto, é preciso considerar outras características, como o vocabulário, as estruturas sintáticas, as imagens, as metáforas, as anáforas... Essa questão discutida no Núcleo é depois discutida com as professoras nas escolas, para que saibam como definir textos adequados para sua turma, de acordo não só com o interesse das crianças mas também com o nível de complexidade do texto.

Finalmente a reflexão sobre a língua, última linha da Figura 2, é um componente que, mais que ser incentivado, precisa ser controlado. No ensino fundamental, foi sempre tradição ensinar desde cedo gramática às crianças: conceitos das classes de palavras, de gênero, número e grau de substantivos e adjetivos, conjugação de verbos, estrutura das orações. Sem que se questione a adequação e utilidade disso para crianças em fase de apropriação da leitura e da escrita. Como se vê na Figura 2, na última linha, denomina-se o componente reflexão sobre a língua, e não gramática, a fim de dar sentido adequado a esse componente: reflexão sobre os recursos que a língua nos oferece para compreendermos textos, e para nos expressarmos por escrito, a nomenclatura sendo secundária.

Como se pode inferir, os componentes da Figura 2 se referem tanto à alfabetização quanto ao letramento. Consciência fonológica e fonêmica, conhecimento das letras, leitura e escrita de palavras referem-se à alfabetização propriamente dita. Os demais componentes estão predominantemente no campo do letramento. No entanto, alfabetização e letramento são indissociáveis, porque, seja qual for o componente, o ponto de partida é sempre o texto. Que seja uma parlenda, que seja um poema, que seja uma história, que seja um texto informativo, que seja um livro, sempre se parte de um texto, que será lido. A leitura do texto, oral ou silenciosa, dependendo da série e dos objetivos da professora, provoca o desenvolvimento de habilidades de compreensão, orientado pelo quadro de estratégias de leitura que foi mencionado anteriormente. Inserido na compreensão do texto está o estudo do vocabulário, enriquecido por aprendizagem de novas palavras, de discussão de processos de formação de palavras por prefixação ou sufixação, sinônimos, antônimos, etc. Partem do texto atividades de consciência fonológica e fonêmica, de leitura de palavras, dele derivam atividades de escrita de palavras, de produção de frases e de textos. Esse processo é representado pela Figura 4, que, como a Figura 2, todas as professoras guardam como um guia: 
Figura 4 - Alfabetização e letramento.

LEITURA

ESTRUTURA DA LÍNGUA

ESCRITA

VOCABULÁRIO

\section{LEITURA}

TEXTO

FRASES

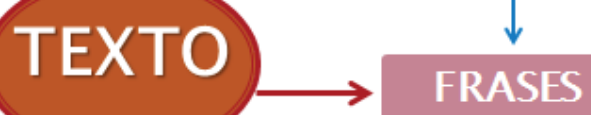

PALAVRAS

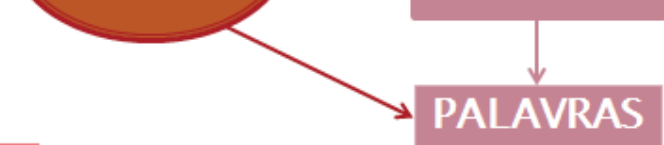

\section{PALAVRAS}
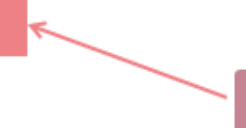

\section{SÍlABAS}

FONEMA

CONSCIÊNCIA

FONOLÓGICAE

FONÊMICA

Por exemplo, a professora de uma turma da educação infantil, crianças de 4 ou 5 anos, lê uma história escolhida criteriosamente de acordo com seus objetivos, explora o vocabulário, propõe perguntas às crianças com o objetivo de desenvolver determinadas habilidades de compreensão, seleciona frase da história para divisão em palavras, palavras da frase para divisão em sílabas, escreve frase e palavras no quadro de giz para que as crianças já associem o oral com o escrito, forma novas palavras com as sílabas, frases podem ser construídas com as novas palavras, finalmente pode ser construído o reconto da história. Parte-se da leitura de um texto e termina-se com a produção de um texto, ao longo desse caminho desenvolvendo-se atividades de letramento e de alfabetização.

Os componentes do processo de alfabetização e letramento se organizam no que é o mais fundamental no Projeto Alfaletrar: a organização em continuidade, integração e sistematização por meio da definição de metas de aprendizagem, estabelecidas para cada ciclo e ano do ensino. As metas foram construídas já na implantação do Projeto, em 2007, e vêm sendo periodicamente atualizadas, na dependência do progresso das crianças e da crescente competência das professoras: estamos agora na terceira versão das metas, e já preparando a quarta versão. Nos Quadros 1, 2 e 3, pode-se ter uma ideia das metas de um dos componentes enumerados no cronograma que foi apresentado, 0 componente leitura, desde o maternal até o 5ํano, e de sua organização em sequência e integração ao longo dos anos: 


\begin{tabular}{|c|c|c|c|}
\hline COMPONENTES & MATERNAL & INFANTIL I & INFANTIL II \\
\hline LEITURA & $\begin{array}{l}\text { RECONHECIMENTO DE PALAVRAS: } \\
\text { - Reconhecer o próprio nome em ficha com } \\
\text { foto ou outro identificador } \\
\text { COMPREENSÃO: } \\
\text { - Responder a perguntas simples sobre } \\
\text { história curta lida ou contada pela } \\
\text { professora. (V. Estratégias de leitura) } \\
\text { VOCABULÁRIO } \\
\text { - Aprender palavras novas encontradas } \\
\text { em histórias lidas pela professora. }\end{array}$ & $\begin{array}{l}\text { RECONHECIMENTO DE PALAVRAS: } \\
\text { - Reconhecer o próprio nome em lista, ficha ou } \\
\text { outro portador. } \\
\text { - Identificar o próprio nome entre nomes de } \\
\text { colegas. } \\
\text { COMPREENSÃO: } \\
\text { - Responder a perguntas sobre história lida pela } \\
\text { professora. (V. Estratégias de leitura) } \\
\text { - Responder a perguntas simples sobre texto } \\
\text { curto informativo lido pela professora. } \\
\text { (V. Estratégias de leitura) } \\
\text { - Recontar história curta lida pela professora com } \\
\text { suficiente informatividade. } \\
\text { - Recontar histórias com base em livros de } \\
\text { imagem (contadas primeiramente pela } \\
\text { professora). } \\
\text { VOCABULÁRIO } \\
\text { - Identificar palavra desconhecida em textos } \\
\text { lidos pela professora, aprender seu } \\
\text { significado e incorporar a nova palavra a seu } \\
\text { vocabulário. }\end{array}$ & $\begin{array}{l}\text { RECONHECIMENTO DE PALAVRAS: } \\
\text { - Reconhecer o próprio nome em lista, ficha ou } \\
\text { outro portador. } \\
\text { - Identificar o próprio nome entre nomes de } \\
\text { colegas. } \\
\text { - Reconhecer palavras de uso frequente na } \\
\text { sala de aula. } \\
\text { - Reconhecer palavra formada com sílabas CV } \\
\text { já conhecidas (com base nas "casinhas"). } \\
\text { COMPREENSÃO: } \\
\text { - Responder a perguntas sobre história lida } \\
\text { pela professora. (V. Estratégias de leitura) } \\
\text { - Responder a perguntas sobre texto curto } \\
\text { informativo lido pela professora. } \\
\text { (V. Estratégias de leitura) } \\
\text { - Recontar história lida pela professora com } \\
\text { suficiente informatividade e adequada } \\
\text { sequenciação dos acontecimentos. } \\
\text { - Contar ou recontar história apresentada só } \\
\text { por meio de imagens (livros de imagem, } \\
\text { tiras e histórias em quadrinhos mudas). } \\
\text { VocABULÁRIO } \\
\text { - Identificar palavra desconhecida em textos } \\
\text { lidos pela professora, aprender seu } \\
\text { significado e incorporar a nova palavra a } \\
\text { seu vocabulário. }\end{array}$ \\
\hline
\end{tabular}

Quadro 2: Metas de leitura - ciclo básico

\begin{tabular}{|c|c|c|c|}
\hline COMPONENTES & $1^{\circ}$ ANO & $2^{\circ}$ ANO & $3^{\circ}$ ANO \\
\hline LEITURA & $\begin{array}{l}\text { LEITURA ORAL E SILENCIOSA: } \\
\text { - Reconhecer, sem necessidade de } \\
\text { decodificação, palavras frequentes em } \\
\text { textos. } \\
\text { - Ler texto ou poema curtos em voz alta } \\
\text { com relativa fluência. } \\
\text { - Ler silenciosamente frases e pequenos } \\
\text { parágrafos, com relativa rapidez. } \\
\text { COMPREENSÃO: } \\
\text { - Recontar história lida pela professora } \\
\text { com informatividade, coerência, } \\
\text { adequada sequenciaçäo dos fatos, } \\
\text { caracterização dos personagens. } \\
\text { - Responder oralmente a perguntas sobre } \\
\text { textos de diferentes gêneros, lidos pela } \\
\text { professora. } \\
\text { (Perguntas orientadas pelo quadro } \\
\text { Estratégias de compreensão, em } \\
\text { nivel de complexidade compativel com } \\
\text { o ano. ) } \\
\text { vocABULÁRIO: } \\
\text { - Incorporar ao vocabulário palavras novas } \\
\text { encontradas em textos, reconhecendo- } \\
\text { as em novos textos. } \\
\text { - Identificar sinônimos de palavras } \\
\text { encontradas em textos. }\end{array}$ & $\begin{array}{l}\text { LEITURA ORAL E SILENCIOSA: } \\
\text { - Reconhecer, sem necessidade de decodificação, } \\
\text { palavras frequentes em textos. } \\
\text { - Ler texto ou poema curtos em voz alta com } \\
\text { fluência e entonação adequada. } \\
\text { - Ler silenciosamente textos curtos de diferentes } \\
\text { gêneros, com rapidez adequada à compreensão } \\
\text { do texto. } \\
\text { COMPREENSÃO: } \\
\text { - Responder oralmente a perguntas sobre textos } \\
\text { narrativos ou informativos lidos pela } \\
\text { professora. } \\
\text { - Responder por escrito a perguntas sobre textos } \\
\text { curtos, de diferentes gêneros, lidos } \\
\text { silenciosamente. } \\
\text { (Para as duas metas: perguntas orientadas } \\
\text { pelo quadro Estratégias de compreensão, } \\
\text { em nivel de complexidade compativel com o } \\
\text { ano. ) } \\
\text { VOCABULÁRIO: } \\
\text { - Incorporar ao vocabulário palavras novas } \\
\text { encontradas em textos, reconhecendo-as } \\
\text { em novos textos e usando-as na produção } \\
\text { de frases e pequenos textos. } \\
\text { - Identificar, em verbete de dicionário lido pela } \\
\text { professora, o significado adequado a } \\
\text { palavra desconhecida encontrada em texto. } \\
\text { - Identificar sinônimos de palavras de texto lido, } \\
\text { determinando a diferença de sentido entre } \\
\text { eles. } \\
\text { - Formar o aumentativo e o diminutivo de palavras } \\
\text { com os sufixos -ão e-inho/-zinho. } \\
\text { - Formar antônimos de palavras encontradas em } \\
\text { textos pelo acréscimo do prefixo de negação } \\
\text { in-/im-. } \\
\text { (Conceito de prefixo.) }\end{array}$ & $\begin{array}{l}\text { LEITURA ORAL E SILENCIOSA: } \\
\text { - Ler texto ou poema em voz alta com fluência, } \\
\text { entonação adequada e compreensão. } \\
\text { - Ler silenciosamente textos de diferentes } \\
\text { gêneros, com rapidez adequada à } \\
\text { compreensão do texto. } \\
\text { COMPREENSÃo: } \\
\text { - Responder por escrito a perguntas sobre } \\
\text { textos de diferentes gẽneros, lidos } \\
\text { silenciosamente. } \\
\text { (Perguntas orientadas pelo quadro } \\
\text { Estratégias de compreensão, em nível } \\
\text { de complexidade compativel com o ano.) } \\
\text { voCABULÁRIO: } \\
\text { - Incorporar ao vocabulário palavras novas } \\
\text { encontradas em textos (inclusive textos } \\
\text { de outras disciplinas), reconhecendo-as } \\
\text { em novos textos e usando-as na } \\
\text { produção de textos. } \\
\text { - Identificar, em verbete de dicionário, o } \\
\text { significado adequado a palavra } \\
\text { desconhecida encontrada em texto. } \\
\text { - Identificar sinônimos de palavras de texto } \\
\text { lido, determinando a diferença de } \\
\text { sentido entre eles. } \\
\text { - Formar novas palavras com base em } \\
\text { palavras encontradas em textos pelo } \\
\text { acréscimo dos prefixos des-, in-/im--irr- } \\
\text { (sentido de negação) e re- (sentido de } \\
\text { repetição). } \\
\text { (Conceito de prefixo.) }\end{array}$ \\
\hline
\end{tabular}


Quadro 3: Metas de leitura - ciclo de consolidação

\begin{tabular}{|c|c|c|}
\hline COMPONENTES & $4^{\circ} \mathrm{ANO}$ & $5^{\circ}$ ANO \\
\hline LEITURA & $\begin{array}{l}\text { LEITURA ORAL E SILENCIOSA: } \\
\text { - Ler texto ou poema em voz alta com fluência, } \\
\text { entonação adequada e compreensão. } \\
\text { - Ler silenciosamente textos de diferentes } \\
\text { gêneros, com rapidez adequada à compreensão } \\
\text { do texto. } \\
\text { COMPREENSÃO: } \\
\text { - Responder por escrito a perguntas sobre textos } \\
\text { de diferentes gêneros, lidos } \\
\text { silenciosamente. } \\
\text { (Perguntas orientadas pelo quadro } \\
\text { Estratégias de compreensão, em nível de } \\
\text { complexidade compativel com o ano.) } \\
\text { vOCABULÁRIO: } \\
\text { - Incorporar ao vocabulário palavras novas } \\
\text { encontradas em textos (inclusive textos de } \\
\text { outras disciplinas), reconhecendo-as em } \\
\text { novos textos e usando-as na produção de } \\
\text { textos. } \\
\text { - Identificar, em verbete de dicionário, o } \\
\text { significado adequado a palavra } \\
\text { desconhecida encontrada em texto. } \\
\text { - Identificar sinônimos de palavras encontradas } \\
\text { em textos, determinando a diferença de } \\
\text { sentido entre eles. } \\
\text { - Identificar, em discurso direto empregado em } \\
\text { textos, os verbos usados para introdução } \\
\text { das falas, incorporá-los ao vocabulário e } \\
\text { usá-los na produção de textos. } \\
\text { mente encontradas em textos, identificar o } \\
\text { processo de formação dessas palavras e } \\
\text { formar novas palavras com esses sufixos. } \\
\text { (Conceito de sufixo.) } \\
\text { construir familia de palavras com a mesma } \\
\text { raiz. (Conceito de raiz de palavras.) }\end{array}$ & $\begin{array}{l}\text { LEITURA ORAL E SILENCIOSA: } \\
\text { - Ler texto ou poema em voz alta com fluência, } \\
\text { entonação adequada e compreensão. } \\
\text { - Ler silenciosamente textos de diferentes gêneros, } \\
\text { com rapidez adequada à compreensão do texto. } \\
\text { COMPREENSÃO: } \\
\text { - Responder por escrito a perguntas sobre textos } \\
\text { de diferentes gêneros, lidos silenciosamente. } \\
\text { (Perguntas orientadas pelo quadro } \\
\text { Estratégias de compreensão, em nível de } \\
\text { complexidade compativel com o ano.) } \\
\text { VOCABULÁRIO: } \\
\text { - Incorporar ao vocabulário palavras novas } \\
\text { encontradas em textos (inclusive textos de } \\
\text { outras disciplinas), reconhecendo-as em } \\
\text { novos textos e usando-as na produção de } \\
\text { textos. } \\
\text { - Identificar, em verbete de dicionário, o significado } \\
\text { adequado a palavra desconhecida encontrada } \\
\text { em texto. } \\
\text { - Identificar sinônimos de palavras encontradas em } \\
\text { textos, determinando a diferença de sentido } \\
\text { entre eles e relacionando a escolha feita pelo } \\
\text { autor do texto com o sentido pretendido. } \\
\text { - Identificar, em discurso direto empregado em } \\
\text { textos, os verbos usados para introdução das } \\
\text { falas, incorporá-los ao vocabulário e usá-los na } \\
\text { produçäo de textos. } \\
\text { - A partir de palavras com os sufixos -eza, -ez, -ês, } \\
\text {-oso encontradas em textos, identificar o } \\
\text { processo de formação dessas palavras e } \\
\text { formar novas palavras com esses sufixos. } \\
\text { (Conceito de sufixo.) } \\
\text { - A partir de palavras encontradas em textos, } \\
\text { construir familia de palavras com a mesma } \\
\text { raiz. (Conceito de raiz de palavras.) }\end{array}$ \\
\hline
\end{tabular}

As metas definem o que toda criança tem o direito de aprender, em cada fase de seu desenvolvimento. Para garantir esse direito e, ao mesmo tempo, a sequência, continuidade, integração e sistematização das metas, todas as professoras e demais profissionais da rede têm os quadros das metas de todos os componentes em um material impresso, de modo que cada uma saiba o que terá sido atingido no ano precedente àquele pelo qual está responsável, e saiba o que seus alunos devem atingir para que a professora do ano seguinte possa dar continuidade ao processo. A referência às metas pelas professoras é constante, seja para mencionar habilidades que estão tendo dificuldades de desenvolver nas crianças, ou o que as crianças têm tido dificuldade de aprender, ou o que tem ou não tem sido atingido em cada ano, o que evidencia que as metas têm dirigido e orientado o ensino e a aprendizagem. 
Do exposto até aqui espero que tenham ficado claros os princípios de continuidade, integração, sistematização em que se fundamenta o Projeto Alfaletrar. Mas lembre-se de que foi indicado um quarto princípio, o acompanhamento do processo de alfabetização e letramento.

\section{Acompanhamento do processo}

Para acompanhar esse processo contínuo, integrado e sistematizado, são realizados diagnósticos periódicos de cada turma, do conjunto de turmas de um mesmo ano em cada escola, e de todas as turmas de um mesmo ano de todas as escolas da rede como um todo. Assim, o mesmo instrumento diagnóstico é aplicado a todas as crianças de um mesmo ano. Os instrumentos são construídos com base em uma matriz elaborada pelo Núcleo e discutida com as professoras nas escolas; a matriz enumera os descritores a serem avaliados, que traduzem as metas, e são distribuídos pelos vários anos, de modo a que se visualize na matriz, e também nos instrumentos diagnósticos, a continuidade das metas e das habilidades a serem desenvolvidas.

Os instrumentos diagnósticos são elaborados pelas professoras que compõem o Núcleo, que para isso consultam as colegas em sua escola, que também colaboram com sugestões e questões; construídos os instrumentos, cada professora realiza o diagnóstico em sua turma, de modo que a autoria da construção, aplicação e análise dos resultados é assumida por todas as professoras e escolas. Os diagnósticos são considerados como indispensáveis mecanismos de acompanhamento da aprendizagem e do ensino, não como uma avaliação de alunos, professoras ou escolas.

Os diagnósticos são feitos em quatro momentos: no início do ano letivo, a fim de que as professoras saibam como as crianças estão chegando a elas, se atingiram as metas do ano anterior, se há metas que precisam ainda ser desenvolvidas ou retomadas; ao fim do primeiro trimestre e ao fim do segundo trimestre, para acompanharmos se as metas em cada ano estão sendo atingidas ao longo do ano, se há dificuldades sobre as quais precisamos refletir e para as quais é preciso buscar soluções; e ao fim do quarto trimestre, já no fim do ano letivo, para sabermos como as crianças estão terminando o ano que cursaram.

Em cada escola, as professoras constroem uma tabela dos resultados de sua turma; os resultados das turmas de um mesmo ano na escola são reunidos em uma tabela do ano pela representante da escola no Núcleo, as tabelas são discutidas pela representante na escola em encontro com as professoras, analisando-se o que vai bem, o que não vai bem, que intervenções são 
necessárias. Finalmente, os resultados das tabelas de cada ano de todas as escolas são reunidos em uma única tabela daquele ano na rede, e as tabelas da rede são analisadas em encontro do Núcleo e, em seguida, em reuniões nas escolas. Isso permite acompanhar com clareza o desenvolvimento de toda a rede, turma por turma, ano por ano, escola por escola, e orientar o trabalho de desenvolvimento profissional das professoras e o suporte a turmas, anos ou da rede que dele necessitem.

A Tabela 1 é um exemplo dos resultados da rede no infantil II (5 anos), no final do ano de 2012:

TABELA 1 - AVALIAÇÃO DIAGNÓSTICA - NOVEMBRO 2012 - RESULTADOS DA REDE AVALIAÇÃO DIAGNÓSTICA - NOVEMBRO 2012 -- RESULTADOS DA REDE

\begin{tabular}{|c|c|c|c|c|c|c|c|c|c|c|c|c|c|c|c|c|c|c|c|c|c|c|c|c|c|}
\hline \multirow{5}{*}{\begin{tabular}{|c} 
I \\
N \\
F \\
A \\
N \\
T \\
I \\
L \\
II
\end{tabular}} & \multirow{5}{*}{ 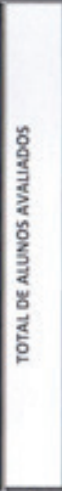 } & \multicolumn{24}{|c|}{ COMPONENTES } \\
\hline & & \multicolumn{14}{|c|}{ 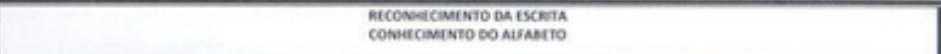 } & \multicolumn{6}{|c|}{ 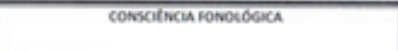 } & \multicolumn{2}{|c|}{ tertuma } & \multicolumn{2}{|c|}{$\begin{array}{l}\text { Iscertix of } \\
\text { mavaved }\end{array}$} \\
\hline & & \multicolumn{2}{|c|}{$\begin{array}{l}\text { DIFERENCLAR } \\
\text { LERAS DE } \\
\text { NÚMEROSE } \\
\text { OUTROSSIMM } \\
\text { OLOS }\end{array}$} & \multicolumn{2}{|c|}{$\begin{array}{l}\text { IDENTIFIAR } \\
\text { EM } \\
\text { DIFERENTES } \\
\text { PORTADORES } \\
\text { DE TEXTO } \\
\text { AQUELE QUE } \\
\text { APRESENTE } \\
\text { SO LETRAS }\end{array}$} & \multicolumn{2}{|c|}{$\begin{array}{l}\text { DISCRIMINAR } \\
\text { LETRAS DE } \\
\text { TRACADO } \\
\text { SEMELUANTE } \\
\text { MAIÚSCULAS } \\
\text { VERSUS } \\
\text { MINUSCULAS }\end{array}$} & \multicolumn{2}{|c|}{$\begin{array}{l}\text { IOENTIFICAR } \\
\text { LETRAS } \\
\text { OUVINDO } \\
\text { SEU NOME } \\
\text { MAIÚSCULAS } \\
\text { MINUSCULAS }\end{array}$} & \multicolumn{2}{|c|}{$\begin{array}{l}\text { ESCREVER } \\
\text { UTRRAS } \\
\text { OUVINDO } \\
\text { SEU NOME. }\end{array}$} & \multicolumn{2}{|c|}{$\begin{array}{l}\text { IDENTIFICAR, } \\
\text { ENTRE } \\
\text { VÁRIAS } \\
\text { SEQUENCIAS } \\
\text { DE LETRAS, } \\
\text { UMAA } \\
\text { DETERMIINAD } \\
\text { A } \\
\text { SEQUENCIA. }\end{array}$} & \multicolumn{2}{|c|}{$\begin{array}{l}\text { RELACIONAR } \\
\text { LETRAS } \\
\text { MAIÚSCULA } \\
\text { SCOOM } \\
\text { LETRAS } \\
\text { MINÚSCULA } \\
\text { S } \\
\text { CORRESPON } \\
\text { DENTES. }\end{array}$} & \multicolumn{2}{|c|}{$\begin{array}{l}\text { IOENTIFICAR } \\
\text { NÚMERO DE } \\
\text { SILABAS EM } \\
\text { PALAVRAS. }\end{array}$} & \multicolumn{2}{|c|}{$\begin{array}{l}\text { IDENTIFICAR } \\
\text { PALAVRAS } \\
\text { QUE } \\
\text { COMECAM } \\
\text { COM A } \\
\text { MESMA } \\
\text { SILABA (CV). }\end{array}$} & \multicolumn{2}{|c|}{$\begin{array}{l}\text { IDENT } \\
\text { PALAVRAS } \\
\text { QUE } \\
\text { TERMINAM } \\
\text { COMA } \\
\text { MESMA } \\
\text { SILABA } \\
\text { (RIMAS). }\end{array}$} & \multicolumn{2}{|c|}{$\begin{array}{c}\text { IDENT } \\
\text { CONCEITO } \\
\text { PALAVRA } \\
\text { ESCRITA: N' } \\
\text { DE PAL EM } \\
\text { FRASE OU } \\
\text { PEQUENO } \\
\text { TEXTO. }\end{array}$} & \multicolumn{2}{|c|}{$\begin{array}{l}\text { ESCREVER O } \\
\text { NOME } \\
\text { COMPLETO } \\
\text { SEM FICHA }\end{array}$} \\
\hline & & \multicolumn{2}{|c|}{ Q.1 } & \multicolumn{2}{|c|}{ Q.2 } & \multicolumn{2}{|c|}{ Q.3 } & \multicolumn{2}{|c|}{$Q .4$} & \multicolumn{2}{|c|}{ Q.s } & \multicolumn{2}{|c|}{ Q.6 } & \multicolumn{2}{|c|}{ Q.7 } & & & & & & 10 & a. & & a. & 12 \\
\hline & & $\begin{array}{l}\mathrm{NE} \\
\mathrm{AC}\end{array}$ & $\mathbf{x}$ & $\begin{array}{l}\text { Ne } \\
\text { AC }\end{array}$ & $*$ & $\begin{array}{l}N+2 \\
A C\end{array}$ & $\mathrm{x}$ & $\begin{array}{l}N= \\
A C\end{array}$ & $\mathbf{x}$ & $\begin{array}{l}N+ \\
A C\end{array}$ & $\%$ & $\begin{array}{l}\text { No } \\
A C\end{array}$ & $\%$ & $\begin{array}{l}N * \\
A C\end{array}$ & $\%$ & $\begin{array}{l}N Q \\
A C\end{array}$ & 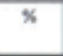 & $\begin{array}{l}\mathrm{NE} \\
\mathrm{AC}\end{array}$ & $\%$ & $\begin{array}{l}\mathrm{NE} \\
\mathrm{AC}\end{array}$ & * & $\begin{array}{l}\mathrm{N}, \\
\mathrm{AC}\end{array}$ & $\%$ & $\begin{array}{l}\mathrm{N} t \\
\mathrm{AC}\end{array}$ & $\bar{x}$ \\
\hline LAPINHA & 7 & 7 & 100 & 7 & 100 & 7 & 100 & 7 & 100 & 7 & 100 & 7 & 100 & 7 & 100 & 7 & 100 & 7 & 100 & 7 & 100 & 7 & 100 & 7 & 100 \\
\hline S. DUMONT & 54 & 54 & 100 & 53 & 98 & 51 & 94 & 49 & 91 & 47 & 87 & 51 & 94 & 49 & 91 & 51 & 94 & 51 & 94 & 50 & 93 & 52 & 96 & 51 & 94 \\
\hline M.AUGUSTA & 11 & 11 & 100 & 11 & 100 & 11 & 100 & 11 & 100 & 11 & 100 & 11 & 100 & 11 & 100 & 11 & 100 & 11 & 100 & 11 & 100 & 11 & 100 & 9 & 81 \\
\hline CLAUDOMIRA & 102 & 99 & 97 & 100 & 98 & 71 & 70 & 97 & 95 & 95 & 93 & 95 & 93 & 96 & 94 & 69 & 68 & 88 & 86 & 90 & 88 & 96 & 94 & 91 & 89 \\
\hline MARUCAS & 45 & 43 & 88 & 45 & 100 & 32 & 71 & 44 & 98 & 42 & 93 & 45 & 100 & 43 & 88 & 35 & 73 & 41 & 91 & 41 & 91 & 44 & 98 & 32 & 71 \\
\hline O.VALADARES & 10 & 8 & 80 & 9 & 90 & 9 & 90 & 9 & 90 & 9 & 90 & 9 & 90 & 9 & 90 & 7 & 70 & 9 & 90 & 8 & 80 & 9 & 90 & 9 & 90 \\
\hline ARAMITA & 17 & 16 & 94 & 17 & 100 & 10 & 58 & 13 & 76 & 10 & 58 & 14 & 82 & 14 & 82 & 08 & 47 & 09 & 52 & 10 & 58 & 15 & 88 & 04 & 23 \\
\hline MESSIAS & 32 & 30 & 94 & 32 & 100 & 29 & 91 & 31 & 97 & 30 & 94 & 30 & 94 & 32 & 100 & 31 & 97 & 29 & 91 & 28 & 88 & 30 & 94 & 32 & 100 \\
\hline M.TEIXEIRA & 22 & 22 & 100 & 22 & 100 & 22 & 100 & 22 & 100 & 21 & 95 & 22 & 100 & 22 & 100 & 21 & 95 & 19 & 86 & 21 & 95 & 22 & 100 & 20 & 91 \\
\hline CEL.PEDRO & 20 & 18 & 90 & 20 & 100 & 18 & 90 & 17 & 85 & 19 & 95 & 19 & 95 & 20 & 100 & 15 & 75 & 20 & 100 & 20 & 100 & 18 & 90 & 10 & 50 \\
\hline NILZA VIEI. & 18 & 15 & 83 & 17 & 94 & 14 & 78 & 16 & 89 & 15 & 83 & 13 & 72 & 15 & 83 & 10 & 55 & 13 & 72 & 16 & 89 & 15 & 83 & 12 & 67 \\
\hline ANTONIO DE C. & 73 & 72 & 99 & 72 & 99 & 65 & 89 & 70 & 96 & 69 & 95 & 71 & 97 & 68 & 93 & 70 & 96 & 72 & 99 & 71 & 97 & 69 & 95 & 66 & 90 \\
\hline CRECHE M. J. & 24 & 24 & 100 & 23 & 96 & 18 & 75 & 20 & 83 & 20 & 83 & 19 & 79 & 18 & 75 & 17 & 71 & 22 & 92 & 22 & 92 & 21 & 88 & 17 & 71 \\
\hline CRECHE N. S.B & 39 & 39 & 100 & 39 & 100 & 38 & 97 & 37 & 95 & 38 & 97 & 38 & 97 & 38 & 97 & 36 & 92 & 39 & 100 & 38 & 97 & 39 & 100 & 34 & 87 \\
\hline TOTAIS & 474 & 458 & 97 & 467 & 98 & 395 & 83 & 433 & 91 & 423 & 89 & 444 & 94 & 442 & 93 & 388 & 82 & 430 & 91 & 433 & 91 & 448 & 95 & 394 & 83 \\
\hline
\end{tabular}

Pode-se identificar na primeira coluna da Tabela 1 as escolas que mantêm educação infantil, na segunda coluna o número de crianças no infantil II de cada escola; nas linhas do alto, os descritores, separados por componente, e o número das questões que avaliam cada descritor. Para cada questão, a primeira coluna apresenta o número de crianças que acertaram a questão, a segunda coluna apresenta a percentagem em relação ao número total de crianças. A cor amarela indica acertos acima de $60 \%$ das crianças; a azul indica acertos entre $40 \%$ e $60 \%$ das crianças, consideradas habilidades em 
construção; a cor vermelha indica resultados fracos, entre $20 \%$ e $40 \%$ de acertos. A cor verde, que não aparece nesta tabela, indicaria resultados nulos, abaixo de $20 \%$ de acertos. A análise da tabela evidencia que, ao final do ano, as crianças do infantil II estão preparadas para o ingresso no ano seguinte no $1^{0}$ ano do ensino fundamental, tendo atingido as metas previstas, estando, portanto, preparadas para as metas do $1^{0}$ ano; por outro lado, a tabela mostra que há uma escola com resultados inferiores às demais - o azul se concentra na linha dessa escola, o que é um alerta para que se identifiquem as dificuldades, das crianças ou das professoras, e se dê o suporte necessário para a superação delas.

As tabelas por turma são semelhantes à Tabela 1, apenas no lugar das escolas, na primeira coluna, ficam os nomes das crianças, de modo que se pode identificar facilmente, pelo uso das cores, em quais descritores houve dificuldades (cor vermelha em colunas) e quais crianças estão enfrentando dificuldades (cor vermelha na linha correspondente à criança). Assim, a tabela torna claros para a professora os resultados da aprendizagem em sua turma e de cada criança individualmente. Cada professora conhece e analisa os resultados de sua turma, e isso acontece quando constrói a tabela e depois quando a analisa com a professora do Núcleo; e cada escola conhece e analisa os resultados de cada uma de suas turmas, em cada ano, em reunião de professoras e diretora sob a orientação da professora do Núcleo, e confrontam suas tabelas com as tabelas da rede, podendo assim avaliar os resultados de sua escola no conjunto. As tabelas da rede têm como principal objetivo verificar se estamos conseguindo o que perseguimos, e de que falei anteriormente: se todas as escolas atingem aproximadamente o mesmo nível de resultados, se estão crescendo igualmente, se a rede toda está conseguindo qualidade de ensino e de aprendizagem.

\section{REFLEXÕES FINAIS}

Para terminar, com base em tudo o que expus até agora, retomo minhas reflexões iniciais sobre a formação de professores para a educação infantil e as séries iniciais do ensino fundamental: os cursos têm formado para o conhecimento e compreensão dos processos linguísticos e cognitivos da aprendizagem inicial da língua escrita e suas implicações para a orientação das crianças? Entretanto, na prática docente, são esses processos linguísticos e cognitivos que os professores precisariam conhecer para traduzi-los em procedimentos, métodos, atividades que promovam e acompanhem o 
desenvolvimento das crianças. É no exercício da profissão, ao defrontarem com a responsabilidade de ensinar as crianças a ler e a escrever, que os professores se ressentem da falta daquilo que deveria lhes ter sido ensinado em sua formação para a profissão. Em Lagoa Santa, frequentemente eu me surpreendia com quanto de essencial as professoras não sabiam a respeito do processo de alfabetização e letramento, a verdadeira revelação que era para elas compreender os processos cognitivos e linguísticos que seus alunos experimentavam tentando aprender a ler e a escrever, e como as dificuldades que crianças enfrentavam eram muitas vezes geradas por ausência de uma orientação adequada e pertinente que não tinham fundamentos para dar.

O projeto de desenvolvimento profissional das professoras em Lagoa Santa, orientado por metas, fundamentado nos princípios de continuidade, integração, sistematização e acompanhamento, construído e realizado em uma permanente interação teoria-prática, tem conseguido um avanço significativo na aprendizagem das crianças e na competência das professoras. Por isso falei em esperança no início desta exposição: a escola pública pode, sim, ter qualidade; talvez o que sobretudo falte, entre, naturalmente, outros fatores, é a formação adequada de professores e estratégias adequadas de desenvolvimento profissional deles, quando já estão em exercício. Penso que é especialmente por isso que devemos lutar, talvez a principal arma para vencermos o reiterado fracasso na alfabetização das crianças deste país.

\section{Nota dos editores}

Étípico das disposições acadêmicas da professora Magda Soares problematizar a experiência e descrever com precisão os princípios e diretrizes que orientam as ações de um processo. Segundo essas disposições, esses elementos são mais importantes que a mera apresentação de bons resultados, pois são eles que fazem o conhecimento avançar. Tomamos a liberdade aqui de, contrariamente a essas disposições e à modéstia que caracteriza a professora, de apresentar os resultados que o projeto vem alcançando. Observa-se que houve considerável evolução do Ideb do município de Lagoa Santa nos anos iniciais do ensino fundamental: de 4,5, em 2007 (quando o projeto foi iniciado), foi para 5,9, em 2013, superando a meta projetada $(5,6)$.

A evolução no desempenho em leitura na Prova Brasil tem sido crescente: em 2007, 30\% dos alunos estavam no nível de aprendizado adequado; em 2011 eram 54\% (aumento de 24\%). Esses resultados são superiores em 6 pontos 
percentuais à média mineira (que em 2007 tinha 28\% de seus alunos no nível adequado e, em 2011, 50\%) e em 19 pontos à brasileira (24\% em 2007 e 35\% em 2011).

No Programa de Avaliação da Alfabetização do Estado de Minas Gerais (Proalfa), a porcentagem de alunos do 30 ano da rede municipal de Lagoa Santa com nível de proficiência recomendado tem aumentado de maneira bastante expressiva: em 2006, era 33,9\%, e em 2012, 84,9\%. 


\section{Public teacher education: an alternative of professional development for alphabetization teachers}

Abstract: This text results from a conference made in Encontros Abertos, that were promoted by Cenpec on September 18, 2013, in which Magda Soares examines alphabetization teachers' education based on her experience in Lagoa Santa (a city in the State of Minas Gerais), where since 2007 she has been working on teachers' professional development and searching to improve education quality in the city. Her experience may suggest principles or guidelines for other teacher education programs.

Keywords: Alphabetization. Teacher education. Curriculum.

RECEBIDO: Abril de 2015.

APROVADO: Abril de 2015. 